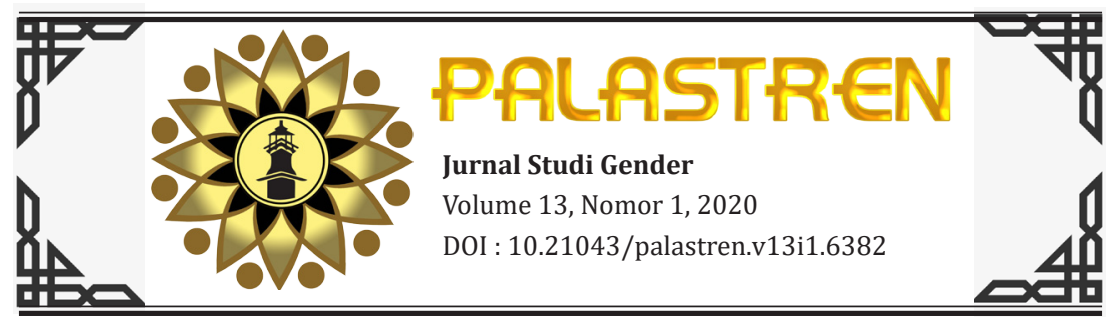

\title{
PEREMPUAN DAN EKONOMI DIGITAL: Peluang Kewirausahaan Baru dan Negosiasi Peran berbasis Gender
}

\author{
Anisa Nurcahyani \\ M. Falikul Isbah \\ Universitas Gadjah Mada, Yogyakarta \\ anisanurca@gmail.com ; falikul.isbah@ugm.ac.id
}

\section{ABSTRAK}

Artikel ini mendiskusikan bagaimana para perempuan pengusaha memanfaatkan media digital sebagai peluang kewirausahaan baru, serta bagaimana mereka menegosiasikan aktifitas ekonomi tersebut dengan peran mereka sebagai istri dan ibu. Berdasarkan riset lapangan di Yogyakarta dengan menggabungkan metode observasi daring atas beberapa akun Instagram milik perempuan pengusaha dan wawancara langsung dengan mereka, riset ini menemukan bahwa ekonomi digital telah menjadi peluang kewirausahaan baru bagi para perempuan pengusaha untuk menjangkau pasar yang lebih luas tanpa mengabaikan peran mereka sebagai istri/ibu. Namun mereka dituntut untuk terus berinovasi dan memahami trend pasar yang terus berubah serta selalu meningkatkan penguasaan teknologi demi hasil yang maksimal. Pada saat yang sama, mereka juga harus mampu menegosiasikan peran domestik dan publik mereka dengan suami. Riset ini menemukan bahwa negosiasi yang berhasil umumnya bertumpu pada kesepakatan dengan suami dalam mengelola waktu, tetap menempatkan keluarga sebagai prioritas, dan memposisikan suami sebagai mitra kerja. Berdasarkan temuan ini, penulis berargumen bahwa ekonomi digital menyediakan peluang kewirausahaan 
baru yang memungkinkan kaum perempuan berperan di ranah domestik dan publik secara negotiable dan fluid (cair atau lentur).

Kata Kunci: Perempuan; Ekonomi digital; Instagram; Gender; Kewirausahaan baru.

\section{ABSRACT}

This article discusses how women entrepreneurs utilize digital media as new entrepreneurial opportunities, as well as how they negotiate economic activities with their roles as wives and mothers. Based on the field research in Yogyakarta by combining online observation method on some of Instagram accounts belonging to women entrepreneurs and direct interviews with them, the research found that the digital economy has become a new entrepreneurial opportunity for them to reach a wider market without neglecting their role as wives/mothers. However, they are required to innovate continuously, to understand the changing market trend, and to always improve their mastery over technology for maximum results. At the same time, they should also be able to negotiate their domestic and public roles with husbands. This research found that successful negotiations generally rests on agreements with husbands in managing time, keeping families as priorities, and positioning husbands as partners. Based on these findings, the author argues that digital economy provides a new entrepreneurial opportunity that enables women to play both their domestic and public roles in a negotiable and fluid way

Keywords: Women; Digital economy; Instagram; Gender; New entrepreneurship.

\section{A. Pendahuluan}

Perkembangan teknologi, terutama media komunikasi digital, telah melahirkan peluang kewirausahaan baru. Media social seperti Facebook dan Instagram menjadi media baru untuk mempromosikan produk, berinteraksi, dan bertransaksi dengan pembeli secara faceless, atau tanpa ketemu-muka antara kedua pihak: penjual dan pembeli. Media digital menjadi alat 
ekonomi yang dapat dimanfaatkan untuk mengembangkan ide, inovasi, dan kreativitas user dalam aktivitas wirausaha usaha (Flanagan, 2018: 5; Wang, 2018: 4340).

Ekonomi digital dapat didefiniskan sebagai sistem baru perekonomian dengan model digitalisasi informasi, komunikasi, dan infrastruktur (Zimmermann, 2018: 73). Sistem ini menghasilkan perubahan kontras terhadap tatanan ekonomi konvensional dimana menekankan interaksi dan transaksi secara tatap-muka (Lohsee, 2018: 84). Salah satu media digital yang tengah massif digunakan untuk wirausaha adalah Instagram (Armstrong dkk., 2016: 157). Instagram selain memiliki fitur ads dan analytica yang membantu wirausaha mempromosikan usaha, platform ini juga mendukung branding pengguna melalui tampilan personal postingan melalui konten foto atau video (Gandini, 2016: 130; Salem \& Salem, 2019). Di Indonesia, Instagram menjadi media sosial yang banyak diakses setelah Facebook dengan jumlah 53 juta akun, sedangkan pengguna Instagram berkisar di usia antara 20-35 tahun (CfDS, 2017; We Are Social, 2018).

Menurut Badan Ekonomi Kreatif (2017), sektor usaha ekonomi digital telah menyumbangkan 852 triliun rupiah terhadap Produk Domestik Bruto (PDB) nasional dengan kontribusi sebesar 7,38 persen terhadap total perekonomian nasional. Sementara, sektor usaha ekonomi digital ini telah menyerap 15,9 juta tenaga kerja dengan proporsi 13,90 persen dari total penduduk kerja sejumlah 114.819.199 jiwa. Dalam kerangka kerja pembangunan perekonomian Indonesia, ekonomi digital dimasukkan dalam rumpun ekonomi kreatif.

Badan Ekonomi Kreatif (2017) menunjukkan bahwa keterlibatan perempuan dalam usaha kreatif 3 kali lebih rendah dibandingkan dengan laki-laki dengan proporsi 22,62 persen dari total tenaga kerja Ekraf sebanyak 15.959.590 jiwa. Meski demikian, keterlibatan ini mencerminkan bahwa perempuan dapat memanfaatkan peluang ekonomi digital dengan cara meningkatkan pemanfaatan teknologi sebagai usaha berdaya secara mandiri dalam sektor ekonomi (Fisher, 2015: 
55; Thackeray, Neiger, \& Keller, 2012: 165). Usaha domestik menjadi pintu masuk wirausaha karena kelekatannya dengan dunia perempuan termasuk sektor fashion, seperti: pakaian, aksesoris, sepatu, jilbab dan tas (García \& Welter, 2013: 389; Hamilton, 2006: 69; Stead, 2017: 62). Peluang yang dimanfaatkan oleh perempuan ini tidak lepas dari pemanfaatan media digital sebagai media promosi (Braches \& Elliott, 2016: 537; Kozinets dkk., 2010; Tuten dan Solomon dalam Sharma \& Kumar, 2018). (Sharma and Kumar 2018)

Sementara itu, tantangan perempuan yang terjun dalam dunia wirausaha dibatasi oleh konteks budaya lokal dan norma-norma keagamaan (Pareek \& Bagrecha, 2017: 468 ; Sakai, 2018: 127). Misalnya kelompok Islam konservatif menentang perempuan bekerja tidak bersama mahram dan bekerja dengan tanggung jawab yang besar. Sebab hal ini akan melalaikan tanggung jawab utama mereka untuk menjalankan tugas-tugas rumah tangga (García \& Welter, 2013: 391; Turner dkk., 2000: 85). Walaupun pendidikan mereka tinggi, setingkat sarjana, perempuan hanya berperan sebagai penghasil pemasukan kedua dalam rumah tangga. Berbeda dengan pengusaha lakilaki menjadi pengusaha karena citra martabat dan gengsi. Kini fenomena baru muncul, yakni perempuan yang berwirausaha karena bagian dari tren gaya hidup (Sakai \& Fauzia, 2016: 15; Jayawarna dkk., 2013: 45)

Artikel ini mendiskusikan bagaimana para perempuan pengusaha memanfaatkan media digital sebagai peluang kewirausahaan baru, serta bagaimana mereka menegosiasikan aktifitas ekonomi tersebut dengan peran mereka sebagai istri dan ibu. Untuk mengeksplorasi dua fokus studi tersebut, penulis menggunakan teori women agency yang dikembangkan oleh Kabeer (2001) dan teori pembagian peran dalam keluarga yang dikembangkan oleh Goode (1983) untuk menjelaskan mengenai negosiasi para perempuan pengusaha dalam menjalankan perannya dalam ranah privat dan publik. Teori women agency membantu mengekplorasi 3 aspek, yaitu resourches, agency dan achievement. Dalam konteks ini, resourches antara lain meliputi 
proses penyiapan sumber daya masnusia, baik secara internal dari perempuan pengusaha maupun eksternal yaitu para pekerja, inovasi yang dikembangkan, dan teknologi yang digunakan untuk mengembangkan usaha. Bagian kedua yakni agency membahas secara detail mengenai pilihan rasional dari perempuan dalam menjalankan perannya berkarir sebagai pengusaha dan sebagai pengatur rumah tangga dalam ranah privat. Hal ini jugalah yang memunculkan pilihan perempuan pengusaha untuk menejemen waktu yang lebih akurat melalui negosiasi peran dalam keluarga. Sementara bagian ketiga, achievement mengeksplorasi capaian para perempuan pengusaha berdasarkan atas sinergi dan dukungan keluarga dalam menghasilkan kinerja yang maksimal. Prestasi tersebut diukur melalui pencapaian dan pengembangan usaha yang dilakukan (Kabeer, 2001: 203).

Sementara itu teori pembagian peran dalam keluarga (cf. Goode, 1983: 87) membantu menjelaskan mengenai pembagian peran dalam keluarga dalam urusan rumah tangga yang bersifat domestik. Beberapa hal yang rinci mengenai hal ini diatur melalui komunikasi oleh pasangan suami dan istri dalam menentukan pembagian peran tersebut. Dalam proses komunikasi ini pasangan suami istri tersebut saling melakukan diplomasi terhadap kegiatan-kegiatan rumah tangga yang dilakukan. Melalui diplomasi tersebut, para pasangan perempuan pengusaha ini menggunakan negosiasi-negosiasi peran yang memungkinkan perempuan pengusaha lebih fleksibel dalam melakukan kegiatan usaha dan mengatur rumah tangga.

Data dalam artikel ini diperoleh melalui sebuah penelitian di wilayah Yogyakarta, dengan alasan bahwa wilayah ini merupakan provinsi dengan pertumbuhan ekonomi kreatif yang tinggi, mencapai Rp243.000.000 untuk ekspor Ekraf dan menduduki 10 besar provinsi dengan ekspor Ekraf tertinggi se-Indonesia (Bekraf, 2017). Penelitian ini menggunakan teknik observasi daring dengan metode fenomenologi, yakni observasi dan penyelidikan pada beberapa akun media sosial Instagram milik para perempuan pengusaha. Kemudian, 
penulis mendalami informasi hasil observasi tersebut dengan mewawancarai para pemilik akun sebanyak 10 informan selama periode Oktober 2018 sampai Mei 2019. Para informan dalam penelitian ini adalah 10 perempuan pengusaha, dengan rentang usia 27-35 tahun dan telah berkeluarga.

\section{B. Pembahasan}

\section{Perempuan Pengusaha sebagai Agensi Berdaya dalam Ekonomi Digital}

Bagian ini mendiskusikan tentang pengalaman dan narasi para perempuan pengusaha yang mencoba memanfaatkan peluang kewirausahaan baru dalam ekonomi digital. Termasuk dalam bahasan ini adalah pengalaman dalam membangun usaha, dan inovasi dan strategi yang dilakukan dalam mengembangkan usaha. Penulis menemukan bahwa para perempuan pengusaha memanfaatkan platform Instagram untuk menjadi peluang usaha melalui marketing daring. Mereka mengikuti tren yang tengah berkembang mengikuti minat customer dan membuat inovasiinovasi dengan mempertajam kreativitas melalui improvisasi produk. Argumentasi yang penulis ajukan pada bagian ini adalah para perempuan pengusaha mengaktualisasikan wawasannya dalam memanfaatkan peluang teknologi digital melalui Instagram untuk meningkatkan profit. Hal ini didiukung dengan paparan para informan mengenai kejeliannya mempelajari strategi marketing daring.

\section{a. Perempuan Pengusaha Menangkap Peluang Kewirausahaan Baru}

Denganadanya teknologi digital, terutama platform Instagram, para perempuan pengusaha terinspirasi untuk memperluas bisnis mereka. Misalnya Alya Mirza, selain sebagai owner pengenliburan.com, dia juga membangun bisnis kedai kopi bernama @muditakopi. Bahkan saat ini dia juga merintis usaha @snackin.id yang menjual snacksnack atau camilan mewadahi Usaha Mikro Kecil dan 
Menegah (UMKM) yang ada di Yogyakarta khususnya. Inovasi yang dilakukan oleh para pengusaha ini meluas spektrumnya apabila ditambah dengan kemampuan mereka menangkap peluang usaha (cf. Hopkinson \& Aman, 2017: 311). Peluang usaha tersebut dimanfaatkan karena pengusaha mampu menangkap peluang yang muncul terhadap tren bahkan mungkin kebutuhan pengusaha tersebut (cf. Beckert, 2017: 507; Elder-Vass, 2016: 228).

Aku butuh duit mbak, aku perlu pundi- pundi makanya melakukan banyak bisnis. Ngeliat tren juga si tapi sekarang lagi model kan anak nongkrong, update kopi, apalagi sinikan deket kampus jadi anakanak suka mampir (wawancara dengan Alya Mirza, 18 Januari 2019).

Pengusaha lain yang juga memiliki bisnis lebih dari satu bisnis diantaranya, Vira Denis. Selain memiliki usaha kuliner @prekju_yk dia memiliki persewaan baby roller. Persewaan tersebut menarik minat dari para ibuibu muda yang travelling dengan membawa bayinya. Memanfaatkan barang yang sudah tidak terpakai menjadi komoditas bisnis tidak saja memberikan pundi-pundi bagi pengusaha tapi juga strategi yang dikembangkan melalui bisnis lain.

Peluang peluang membuka usaha baru tersebut juga dimanfaatkan oleh informan lain seperti Reisa Nurma yang memiliki usaha kuliner, @jogjanasibento. Lalu, Rahma Fauzia selain sebagai owner @ heratpartydecoration, juga memiliki usaha fesyen @ hijaraya. Tria Meriza juga membuka usaha baru selain @simplyhomy_guesthouse, seperti fesyen @albatique dan @sofeya.id, oleh-oleh, snack, dan kuliner. Elita Barbara selain mempunyai usaha @elitakerudung, juga mengembangkan outfit fesyen top to toe bagi customer. Iris Haribaning konsisten menekuni usaha kuliner @ pikameame juga mengembangkan @bacil dan steamboat 
shabu suki dan mozzarella stick. Peluang kewirausahaan baru yang dimanfaatkan oleh para pengusaha ini menggambarkan bahwa mereka berkembang secara bertahap setelah mapan pada usaha yang telah mereka bangun sebelumnya (cf. Angel., dkk 2018: 615).

Berdasarkan paparan tersebut, perempuan pengusaha menciptakan peluang kewirausahaan baru dengan memanfaatkan Instagram sebagai sarana marketing daring (Allen, 2018: 592). Inovasi perempuan pengusaha supaya tetap eksis dalam dunia wirausaha ini mereka wujudkan dalam banyak pencapaian di bidang usaha, termasuk dengan cara memanfaatkan peluang usaha baru. Inovasi-inovasi ini juga mereka artikulasikan dengan mengasah kreativitas dalam menghasilkan produk, merepresentasikan konten, dan mengaplikasikan strategi marketing daring (cf. Kemper \& Ballantine, 2017: 384). Para perempuan pengusaha ini juga fokus menyasar segmentasi pasar yang menjadi target mereka dengaan memahami karakter unggahan maupun intensitas kecenderungan mereka melihat tren di media sosial (cf. Bal dkk., 2015: 195).

\section{b. Inovasi dan Pemahaman atas Trend Pasar}

Inovasi yang dilakukan para pengusaha perempuan bertumpu pada pemahaman mereka atas selera pasar yang berubah terus-menerus. Lebih dari itu, posisi mereka sebagai perempuan secara kultural turut membantu ketajaman naluri dalam memahami dinamika pasar di beberapa sektor bisnis yang mereka geluti, seperti fesyen dan kuliner. Berikut beberapa inovasi yang kami temukan selama proses riset.

Pertama, kami menemukan berbagai upaya mereka untuk meningkatkan kapabilitas sebagai pengusaha, juga kapabilitas karayawan mereka. Iffah M Dewi dan Tria Meriza Kedua, dua perempuan pengusaha di bidang fesyen, mengakui pentingnya belajar mengenai bisnis 
bersama dengan ahlinya. Ahli yang mereka maksud bisa berasal dari akademisi atau sesame pengusaha yang terbilang sukses. Mereka juga mengadopsi model coaching atau semacam pendampingan proses bisnis. Menurut mereka, coaching dapat menjadi kontrol terhadap bisnis yang mereka kembangkan selain meningkatkan kapabilitas mereka dalam mengelola usaha.

Sementara itu, mereka juga kerap diminta berbagi ilmu atau bahkan melakukan coaching bagi pengusaha lain yang levelnya masih di bawah mereka. Proses ini membuat mereka memiliki pengaruh yang kuat dalam lingkaran para perempuan pengusaha. Selain itu, mereka juga melakukan engagement melalui Instagram sehingga menempatkan mereka sebagai panutan atau role model bagi followers.

Proses peningkatan kapasitas juga mereka lakukan terhadap karyawan mereka. Misalnya, pengusahapengusaha ini menugaskan karyawannya untuk mengikuti pelatihan atau seminar yang berkaitan dengan daring marketing berbayar secara rutin untuk kepentingan mengembangkan strategi marketing. Kegiatan coaching dan seminar bagi karyawan tersebut dilakukan oleh pengusaha seperti Reisa Nurma, Iffah M Dewi, Alya Mirza, dan Elita Barbara.

\begin{abstract}
Aku nyekolahin karyawanku buat ngikutin pelatihan-pelatihan marketing gitu, secara berbayar, kalo ada undangan atau tau info-info seminar atau pelatihan berbayar gitu dibiayain aku suruh ikut buat pengetahuan dia juga kan (wawancara dengan Reisa Nurma, 11 Januari 2019)
\end{abstract}

Dengan kapasitas yang terus ditingkatkan dan engagement yang konsisten pada dunia digital, mereka mengaku menjadi lebih responsif terhadap perkembangan tren-tren dari dunia sosial yang tengah berkembang. Proses perubahan diri sebagai perempuan 
beda generasi misalnya dapat diidentifikasi melalui sikap dan intensitasnya menggunakan teknologi. Hal ini juga yang mendasari para perempuan pengusaha dapat memetakan segmentasi pasar dan skala usaha mereka melalui media sosial (cf. Katana, 2014). Namun, media sosial juga menyimpan resiko dalam aktivitasnya menyusuri dunia cyber, resiko-resiko pemanfaatan teknologi tersebut yang dikelola dan direduksi oleh para perempuan pengusaha ini. Lebih lanjut, mereka menggunakan kemampuan mitigasi tersebut sebagai upaya untuk mengembangkan kapabilitas mereka dalam menggeluti dunia wirausaha. Berikut ini, cara-cara yang gunakan oleh mereka untuk memanfatkan teknologi sebagai media berwirausaha secara digital.

Kedua, penggunaan media sosial untuk promosi bisnis. Berdasarkan data wawancara, diketahui bahwa para perempuan pengusaha menggunakan media sosial untuk kepentingan promosi bisnis. Media sosial yang paling banyak digunakan adalah Instagram. Mereka memilih menggunakan Instagram selain karena perubahan tren, juga karena Instagram mendukung strategi promosi bisnis yang memerlukan luas. Disamping itu, para pengusaha ini juga menggunakan jasa Instagram ads untuk kepentingan memetakan minat dan segmentasi pasar (cf. Grewal dkk, 2019). Beberapa pengusaha yang menggunakan Instagram ads antara lain Iffah M Dewi, Tria Meriza, Anisa Yona, Reisa Nurma, Vira Denis, Rahma Fauzia, Elita Barbara dan Iris Haribaning.

Aku pake karena itu ngebantu banget kita tau segmentasi pasar kita di umur berapa. Instagram ads, line ads, kita juga bisa tau segmentasi target kita lebih suka sama tren apa sih? (wawancara dengan Elita Barbara, 24 Februari 2019).

Selain menggunkan Instagram ads, Elita Barbara juga menggunakan fitur lain seperti Line ads. 
Pemilihan fitur ads berbayar yang disediakan oleh aplikasi ini memungkinkan tim marketing Elita mampu mengetahui dan mengidentifikasi segmentasi pasar dan perkembangan ketertarikan customer terhadap produk tertentu. Identifikasi marketing menentukan secara cermat para pengusaha dalam menentukan target pasar dan produk yang dihasilkan (cf. Tham, 2015: 590).

Ketiga, membuat konten yang menarik untuk mendorong pemasaran. Pembuatan konten yang menarik dimulai dari penyusunan layout, desain grafis, konsistensi warna dan huruf yang digunakan, penyusunan caption, hashtag serta waktu pengunggahan yang tepat. Strategi tersebut telah berkembang dari tren sebelumnya misalnya dengan membuat anak-anak akun official. Pembuatan konten untuk Instagram pun tidak terlepas dari perencanaan yang panjang oleh para content leader-nya. Bahkan, untuk bidang penyusunan konten ini dibutuhkan planning yang matang dan berbagai pertimbangan. Untuk fashion sebagian besar mereka membuat konten disesuaikan dengan tema tertentu. Karena itu, mereka menyiapkan anggaran khusus untuk pembuatan konten tersebut. Seperti yang dilakukan oleh Elita Barbara, untuk memproduksi sebuah konten di Instagram, dia bisa menghabiskan anggaran Rp10.000.000. Misalnya dengan tema konten travelling, budget tersebut dipergunakan untuk membeli tiket pesawat, hotel, transportasi, dan lain-lain.

Dalam penyusunan konten tersebut, apalagi melalui media social, skill fotografi sangatlah penting. Beberapa pengusaha memilih untuk menggunakan jasa vendor untuk melakukan pembuatan konten, seperti Vira Denis. Sedangkan beberapa pengusaha lain seperti Reisa Nurma, Iris Haribaning, Elita Barbara, Rahma Fauzia, Anisa Yonasari menggunakan outsourching untuk melakukan pekerjaan yang bergelut dengan fotografi ini. Kaitannya dengan media sosial yang banyak memainkan 
grafis, pilihan konten yang eye-catching dan gaya-gaya Instagramable sangat menopang viewer yang signifikan yang berdampak pada peningkatan penjualan produk.

Konsistensi mereka dalam memilih karakter menjadi pertimbangan penting dalam pembuatan konten dan merepresentasikan segmentasi pasar yang menjadi target. Karakteristik dari setiap usaha mereka juga menentukan dalam pembuatan konten seperti konsisten memiliki konsep natural, ceria, muda, elegan, premium, sporty, relax dan etnik. Kesan natural tampak pada konten milik @reisagarage. Seringkali konten yang dihasilkan memadukan kesan natural antara mahasiswi dan kampus, kesan nyaman dan fleksibel namun tetap modis. Sedangkan, @PLVDsports dengan karakternya yang sporty menghasilkan konten yang berhubungan erat dengan pola hidup sehat, aktivitas gym dan membagikan tips hidup sehat. Begitu pula dengan Elita kerudung membawa konsep ceria, konten yang dihasilkan berkaitan dengan tone warna-warna yang cerah dan mencolok, banyak mengunggah konten refreshing tentang kegiatan liburan.

Kalo deathstock misalnya, udah kacau tuh, aku harus gimana? ah bikin aja konten baru yang lebih menarik visual customer (wawancara dengan Reisa Nurma, 11 Februari 2019).

Pentingnya membuat konten produk juga disepakati oleh para perempuan pengusaha fashion termasuk Reisa Nurma, saat usahanya mengalami deathstock atau stock barang menumpuk. Cara yang Reisa Nurma lakukan adalah membuat konten produk yang baru untuk mempromosikan produk tersebut dengan visual yang lebih menarik, seperti koleksi stripetee. Akibat Deathstock, pengusaha akan menimbulkan timbunan produk serupa, karena usaha harus tetap berjalan, maka dibuatlah konten baru yang mampu menarik minat 
customer, bisa jadi konten tersebut berbeda dari konten pertama sebelum di restock. Sementara itu, Vira Denis yang memiliki bisnis @prekju_yk bermain dengan cara yang lebih aman untuk mengatasi deathstock. Dia secara sistematis memetakan stock yang akan dikirim kepada agen franchise dengan menggunakan sistem komputasi media digital. Sistem komputasi ini membantu untuk mengontrol seberapa banyak target penjualan yang mampu dicapai oleh cabang tertentu.

Keempat, kami menemukan penggunaan jasa influencer dalam mempromosikan produk. Influencer digunakan untuk menggaet promosi yang lebih luas, promosi tersebut secara luas ditujukan kepada followers yang dia miliki (CfDS, 2019). Influencer adalah pemilik akun media social dengan pengikut yang sangat banyak. Mereka bisa berasal dari kalangan artis, politisi, atau microselebriti (orang terkenal berkat aktifitas dan kreatifitas di media social seperti tweeter, youtube, and instagram).

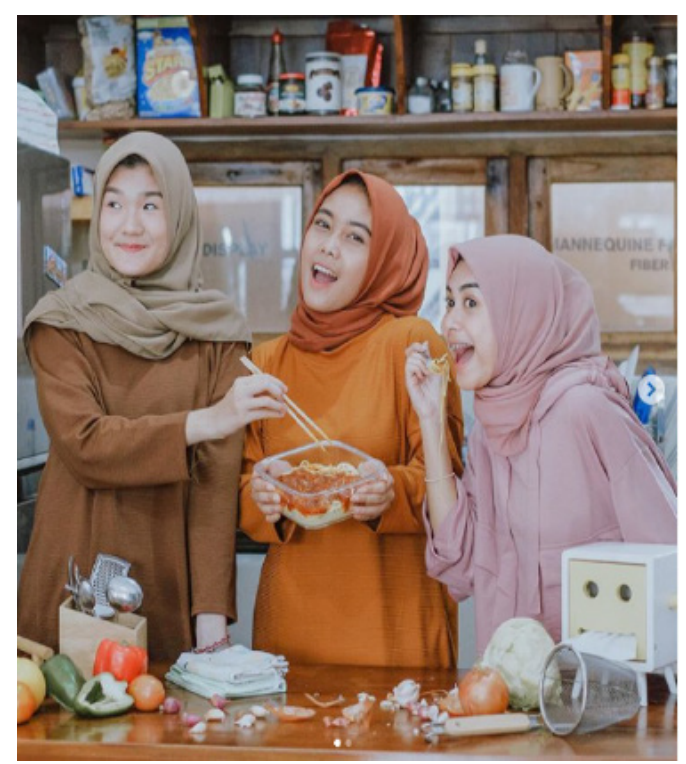

Gambar 1: Tampilan unggahan elita kerudung dengan ifluencer. |Sumber:https://www.instagram.com/p/BOYZREiHz-I/ 
Pemilihan strategi marketing menggunakan influencer ini dianggap memiliki engagement yang kuat terhadap para followers-nya, terutama selebgram (Heinonen and Medberg, 2018). Endorsement oleh selebgram sendiri dilakukan atas kesepakatan dengan pebisnis, yang meliputi besaran honor atau tarif, durasi dan frekuensi postingan, serta jenis konten.

kami nggak ada kontrak sih sama selebgram, karena kan mereka bukan professional model ya, tapi dalam bentuk kerjasama aja, free produk atau mereka minta tarif berapa ( $R N$, wawancara dengan Reisa Nurma,11 Februari 2019)

Para selebgram yang mengasah skill modeling bergabung dalam agency untuk menjadi model profesional. Melalui agency tersebut beberapa model yang menjalin kontrak menjadi brand model dari usaha-usaha mereka. Sogan Batik misalnya, mereka menggunakan jasa model profesional untuk mempromosikan produk, untuk menunjang profesionalitas tersebut sistem kerja mereka diberlakukan dengan kontrak.

\section{c. Tantangan Menggunakan Teknologi untuk Ekonomi Digital}

Riset ini menemukan bahwa para perempuan pengusaha mempunyai tantangan dalam menggunakan teknologi untuk mengembangkan usahanya. Hai ini terkait menyingkronkan antara kapasitas pengusaha dan pemanfaatan media digital. Mereka mengemukakan bahwa mereka memiliki kendala untuk menyesuaikan dengan perkembangan pesat media digital.

Harus belajar lagi, harus banyak belajar, dan harus banget cepet belajar kalo sampe kelewatan ya kita ngga dapet. Harus ngikutin (wawancara dengan Alya Mirza, 29 Januari 2019) 
Menurut Anisa Yona, perkembangan pesat teknologi membuatnya harus terus belajar tentang media digital. Hal serupa juga diungkapkan oleh Vira Denis, Elita Barbara, Novi Ana, Iffah M Dewi, Tria Meriza, Rahma Fauzia, Alya Mirza, dan Reisa Nurma. Mereka berusaha menyesuaikan dan mengikuti tren yang berkembang saat ini. Melalui penyesuaian tersebut mereka menemukan celah-celah menangkap peluang ekonomi.

Berdasarkan wawancara dengan mereka, setidaknyaada tiga area tantanganyang menjadiperhatian mereka: kesulitan membangun representasi yang tepat atas produk, kesulitan menggambarkan produk jasa, dan kesulitas mengikuti trend produk kuliner yang terus berubah. Misalnya, Tria Meriza masih memiliki kesulitan untuk membuat konten yang merepresentasikan maksud/ makna filosofis produk walaupun dia sudah membuat visualisasi yang baik. Selanjutnya, tantangan yang dialami dari pengusaha sektor jasa dihadapi oleh Rahma Fauzia yang berusaha membuat video yang mencakup before-after dekorasi. Beberapa pengusaha di sektor kuliner seperti Iris Haribaning dan Vira Denis lebih condong untuk menghadapi tantangan secara fisik seperti tren varian rasa, topping, dan snack kekinian.

Berdasarkan riset ini, penulis mendapati bahwa perempuan pengusaha berupaya gencar beradaptasi dengan tren perkembangan media digital utamanya media sosial yang terus bergerak pesat dan menciptakan model-model baru dalam kehidupan sosial (cf. Armstrong, 2016: 149). Hal ini menjadi tantangan sekaligus perjuangan tersendiri bagi para perempuan pengusaha ini terutama dalam memanfaatkan teknologi dan mengelola ide untuk diasah dan dimanfaatkan untuk kepentingan ekonomi (cf. Kabeer, 2001: 108). Apalagi, mereka masih perlu menyesuaikan diri dengan terus melakukan update tren selera dan perilaku belanja pasar. 


\section{Negosiasi Perempuan Pengusaha dalam Peran Domestik dan Publik}

Pada bagian ini penulis mendiskusikan negosiasi peran para perempuan pengusaha berdasarkan gender mereka dalam fungsi domestik dan publik. Mereka menempatkan diri mereka dalam dua ranah: pertama sebagai pengusaha yang memiliki produktivitas tinggi di ruang publik sebab tidak hanya berurusan dengan para karyawan usaha tetapi juga dengan jaringan, komunitas dan customer. Kedua, para wirausaha ini juga berperan sebagai seorang perempuan yang sangat bersinggungan dengan kehidupan domestik seperti merawat anak, berkeluarga, dan serba serbi kehidupan rumah tangga lainnya. Mereka menggunakan waktu untuk berperan pada dua ranah ini, sehingga mereka harus bisa mengelola bagaiamana mereka harus berinteraksi, bersikap dan memposisikan diri (cf. Antonio \& Tuffley, 2014: 679).

Negosiasi peran berbasis gender seperti ini terjadi ketika seorang perempuan harus menyingkronkan atau menjaga keseimbangan antara tuntutan profesionalitas kerja sebagai pengusaha di ruang publik dan posisi sebagai istri dan ibu pada ranah domestik (Ratten \& Dana, 2017: 65). Negosiasi peran seperti ini tidak bersifat saklek dan harus memisahkan ranah publik dan domestik secara tegas, namun lebih menuntut kemampuan mereka dalam merepresentasikan peran tersebut secara akurat (Martínez-Cantos, 2017: 424). Negosiasi peran juga dapat diartikan sebagai adaptasi perempuan dalam peran professional mereka di tengah keharusan-keharusan kultural dalam ranah domestic (Essers \& Benschop 2009: 411; Fakih, 2008: 37). Dalam riset ini, penulis mendapati para pengusaha perempuan menegosiasikan posisi dan mengartikulasikan peran mereka melalui cara-cara berikut.

Riset ini menemukan bahwa proses negosiasi yang berhasil menciptakan dukungan bagi kegiatan wirausaha mereka terjadi dalam beberapa bentuk, yakni manajemen waktu, kesepakatan 
bahwa keluarga adalah prioritas, mempekerjakan asisten rumah tangga dan menitipkan anak di daycare, serta memposisikan suami sebagai mitra kerja.

\section{a. Manajemen Waktu sebagai Kunci}

Para perempuan pengusaha yang menjadi informan penelitian ini mengungkapkan bahwa kunci dari berjalannya usaha dan kehidupan rumah tangga mereka adalah manajemen waktu. Hal ini dapat berjalan sinkron dikarenakan daya mereka dalam membagi waktu yang akurat antara ranah domestik dan publik. Seperti dikatakan oleh Novi Ana, owner @witbatikcraft,

Ya aku juga bingung. Tapi ya bisa sih, aku ke LKiS jam 10.00-17.00 kalo ngga ada acara ya. Sore malem baru sama anakku. Kalo suamiku kan juga kerja jadinya kita paling kalo main atau kegiatan gitu sabtu sama minggu full untuk keluarga gitu. Tapi Sabtu itu biasanya aku masih gunain ntuk ngurusin usahaku tak sambi (wawancara dengan Novi Ana, 17 Januari 2019)

Dia merasa kebingungan untuk menjelaskan bagaimana dia membagi waktu untuk kedua dunianya. Tetapi menurutnya, pembagian waktu yang jelas dan rinci membuat dia lebih mudah mengelompokkan dan membuat lebih sistematis dalam memanfaatkan waktu luangnya. Informan lain seperti Tria Meriza, Anisa Yona, Iris Haribaning, Reisa Nurma misalnya secara sistematis menuliskan agendanya dalam buku agenda, sehigga, mereka benar-benar bisa memanfaatkan waktu secara produktif.

Kendala-kendala yang paling sering muncul dan mengubah agenda tersebut adalah karena mereka sendiri juga terbatas menggunakan waktu karena memiliki anakanak antara lain Bayi Tiga Tahun (Batita) dan Bayi Lima Tahun (Balita). Hal ini menurut mereka cukup membuat mereka kurang akurat membagi waktu walaupun sudah ada agenda yang direncakan dengan baik. 
Hal itu juga dialami oleh Iffah M Dewi, karena dia memiliki anak usia menginjak balita, dengan dayanya dia memanfaatkan waktunya untuk mengurus anak dan juga berwirausaha. Kerepotannya mengurus anak merupakan kendala yang tidak dapat diperkirakan. Misalnya, dalam sehari dia bisa melakukan controlling langsung ke lokasi kerja sebanyak lebih kurang 6 jam. Tetapi karena anaknya masih balita dan belum mengerti kesibukan ibunya, Iffah $\mathrm{M}$ Dewi hanya bisa menggunakan waktu lebih kurang 2 jam di lokasi kerja. Namun, di waktu lain ketika anaknya tidak rewel, dia bisa produktif dengan jam kerja lebih dari 8 jam.

Nggak tentu, kalo lagi rewel gini paling bisa kerja 2 jam di kantor. Tapi kalo pas bisa disambi ya lancar, malahan bisa controlling lama (wawancara dengan Iffah M. Dewi, 29 januari 2019)

Iris Haribaning mengatakan bahwa anakanaknya sudah biasa membantu pekerjaannya, maka dia tidak terlalu kerepotan mengurus ketiga anaknya, walaupun anak bungsunya masih Batita. Namun untuk benar-benar meluangkan waktu bersama keluarga dia juga mengalami kesulitan. Alhasil untuk menghadiri pertemuan-pertemuan keluarga dia banyak mewakilkan pada suami atau mereka datang ke acara keluarga besar secara bergantian. Jika tidak datang secara bergantian, maka dia membutuhkan persiapan yang matang untuk meluangkan waktu berkumpul bersama keluarga besar. Hal serupa juga dirasakan oleh Tria Meriza, Anisa Yona, Reisa Nurma, Alya Mirza, Rahma Fauzia dan Elita Barbara, mereka mengungkapkan adanya agenda untuk berkumpul bersama keluarga besar sangat jarang terjadi, persiapan yang matang, jauh-jauh hari adalah cara terbaik untuk mengantisipasi pekerjaan pada waktu acara tersebut berlangsung.

Para perempuan pengusaha ini menjadikan model "co-pilot" dalam melaksanakan tugasnya, mereka 
menyadari bahwa tidak semua pekerjaan harus mereka lakukan. Mereka secara akurat memilah pada hal yang mana mereka memfokuskan usaha, dan beberapa pekerjaan mana yang mungkin mereka delegasikan untuk membantu beban pekerjan mereka (cf. Stead, 2017: 64). Sebab, menurut Anisa Yona, walaupun kerja seorang wirausaha fleksibel tetapi, mereka bisa memiliki jam kerja yang digunakan untuk controlling usaha lebih besar dari jam kerja normal, bahkan beberapa perempuan pengusaha selain Anisa Yona, Iris Haribaning mengatakan jam kerja mereka bisa lebih dari 12 jam. Hal ini dikarenakan untuk beberapa pekerjaan mereka belum memiliki karyawan yang spesifik mengerjakan hal tersebut, untuk order atau untuk pengecekan barang yang membutuhkan waktu misalnya mereka harus turun tangan ke gudang.

\section{b. Menempatkan Keluarga sebagai Prioritas}

Meski memiliki jadwal kesibukan yang luar biasa, para perempuan pengusaha ini mengungkapkan bahwa waktu bersama keluarga mereka prioritaskan. Mereka yang sudah memiliki anak cenderung memperhatikan secara cermat pendidikan, pola asuh, bahkan asupan makanan yang diberikan (cf. Esser \& Benschop, 2009: 408). Tria Meriza, Reisa Nurma, Vira Denis, Anisa Yona, Iris Haribaning memasakkan sendiri makanan untuk anak-anak mereka. Bagi para perempuan pengusaha ini, keluarga adalah pengerem segala ambisinya dalam bekerja. Seperti yang dikatakan Alya Mirza, ketika dia sudah over untuk melakukan sesuatu yang sudah sekiranya melebihi batas kemampuannya, suami Alya Mirza akan menahan dia melakukan pekerjaan itu, dan menyarankan agar dia bersikap lebih santai.

Suamiku yang nge-rem kalo aku udah over, kalo apa - apa pengen aku kerjakan (wawancara dengan Alya Mirza, 18 Januari 2019) 
Selain itu, Alya Mirza ini juga tengah menantikan lahirnya anak pertama sama dengan yang tengah dirasakan Rahma Fauzia. Karena itu, dia merasa bahwa dia harus mengurangi pekerjaan karena mereka juga memerlukan istirahat dari rutinitas yang padat untuk kebutuhan calon anaknya. Sebab itu, mereka juga mulai memikirkan bagaimana mereka bekerja dengan relax, beberapa hal yang mereka tegaskan adalah mulai mencari orang-orang yang mereka percayai sebagai asistan mereka dan bertanggungjawab terhadap beberapa tugas pekerjaan yang mereka lakukan saat ini. Lebih dari itu, jika dulu mereka banyak melakukan aktivitas di luar ruangan seperti halnya Alya Mirza yang melakukan travelling karena mengantar rombongan tour, dia mulai mengururangi aktivitas itu. Begitu juga yang dilakukan oleh Rahma Fauzia, dia juga mulai mendelegasikan beberapa pekerjaan kepada timnya, sehingga dia hanya beberapa kali waktu melakukan cek, controlling, dan beberapa waktu untuk bertemu dengan customer.

\section{Ummu wa robatul bait, ibu dan pengatur rumah tangga, bisnis bagi wanita mubah dibandingkan seorang ibu. Kewajibannya mana, gampang kalo udah tau konsepnya (wawancara dengan Tria Meriza, 22 Februari 2019)}

Tria Meriza mengungkapkan bahwa prinsipnya mengacu pada ajaran agamanya yang menyebutkan bahwa ummu warobatul bait, yang artinya tanggung jawab seorang perempuan adalah sebagai seorang ibu dan pengatur rumah tangga. Prinsip tersebut dia terapkan dalam mengatur sudut pandang bahwa keluarga adalah prioritas jika dibandingkan dengan kegiatan berwirusahanya. Walaupun demikian, dia secara diplomatis menyebutkan bahwa berwirausaha boleh dilakukan dengan cara menambah pahala pada setiap kegiatan yang dilakukan, misalnya berwirausaha di jalan Tuhan, dalam arti mengikuti syariat Tuhan. Elita Barbara 
lebih menekankan pada rasa percaya pada sang suami. Hal tersebut dikarenakan dia dan suaminya menjalani profesi yang berbeda bidang sehingga mereka sangat fleksibel untuk melakukan pekerjaan masing-masing sesuai dengan profesionalitas bekerja mereka.

Suami para perempuan pengusaha ini juga fleksibel dalam membantu merawat anak mereka, sebab cara mengurus anak bagi pasangan pengusaha ini dilakukan bersama-sama dan tidak hanya dilakukan oleh perempuan. Anisa Yona sangat concern terhadap pendidikan anak, namun dia juga terbuka dan membagi pekerjaan merawat anak bersama suaminya. Mereka bergantian merawat anak karena bagi mereka aktivitas anak harus selalu diawasi dan penting bagi pekembangan psikologis, motorik, dan kognisi mereka. Mereka memilih berdamai dan diplomatis menyangkut dengan kepentingan dan kebutuhan untuk merawat anak.

\section{c. Mendelegasikan Pekerjaan Rumah dan Menggunakan Jasa Daycare}

Perempuan pengusaha mengutamakan pendidikan yang terbaik bagi anak-anak mereka disertai dengan pertimbangan-pertimbangan yang matang, yang dapat mengakomodir kebutuhan anak-anak mereka. Pendidikan anak bagi para perempuan pengusaha ini penting dipertimbangkan, tidak hanya mengenai pola asuh tetapi juga mereka menekankan pendidikan yang dapat mengasah bakat anak-anak mereka. Beberapa informan seperti Reisa Nurma, Anisa Yona, Iffah M Dewi, memilih daycare untuk mendidik anak-anak mereka. Alasannya, selain mereka dapat belajar secara privat karena dari sisi akademik guru-guru mereka benarbenar memperhatikan pertumbuhan dan perkembangan anak-anak secara detail satu per satu anak mereka juga dapat mengeksplorasi kebebasan mereka dalam proses pembelajaran (cf.Rioux \& Parylak, 2016: 40). 
anak anak kan sekolah sampe sore di boarding school, jadi bundanya juga bisa produktif kerja. Dia (anaknya) banyak kegiatan sampe rumah cape, jadi makan malam terus tidur (wawancara Tria Meriza, 22 Februari 2019)

Anak-anak yang sekolah di daycare bernegosiasi dengan orangtuanya yang sibuk, jadi karena mereka sudah belajar di sekolah daycare sampai sore, sehingga orangtua dapat bekerja. Sedangkan Iris Haribaning dan Tria Meriza memilih boarding school selain karena jenjang pendidikan anak mereka sudah lebih tinggi bukan lagi balita, mereka mengharapkan output dari sekolah boarding school tersebut yang lebih merepresentasikan keinginan mereka mendidik anak-anak, dalam hal ini ilmu agama Islam.

Nggak aku nggak masak, urusan rumah masak nyuci dalan lain-lain aku kasih ke delegasikan ke asisten rumah tangga (wawancara dengan Alya Mirza, 18 Januari 2019)

Sementara mengenai tugas rumah tangga atau pekerjaan domestik, para perempuan pengusaha ini memilih mendelegasikan pekerjaan tersebut kepada asisten rumah tangga. Pekerjaan domestik tersebut meliputi, memasak, mencuci, membersihkan rumah dan lain-lain. Mereka memilih mengunakan jasa asisten rumah tangga untuk meringankan beban mereka selama di rumah. Beberapa informan seperti Anisa Yona dan Rahma Fauzia, karena kegemarannya memasak mereka tetap melakukan hal tersebut dalam beberapa waktu, namun jika mereka sudah merasa kerepotan mereka memilih asisten untuk membuatkan masakan. Adanya asisten rumah tangga tersebut menurut mereka bagian daripada delegasi pekerjaan yang mereka lakukan, sebab mereka tidak lagi mengurus rumah dan serba serbi tetapi mereka juga tetap mengecek, mengontrol, dan 
mengagendakan bagaimana mereka akan menggunakan waktu dan pekerjaan mana yang akan dilakukan oleh asisten rumah tangga mereka (cf. Meliou \& Edwards, 2018: 157).

\section{d. Suami sebagai Mitra Kerja}

Para perempuan pengusaha ini menjadi hebat dan tangguh karena dukungan suami mereka. Semua informan dalam penelitian ini mengungkapkan betapa besar support suami mereka terhadap kegiatan wirausaha yang mereka lakukan. Selain itu, para suami juga siap membantu pekerjaan wirausaha para perempuan wirausaha ini baik dari segi waktu, tenaga dan materi. Reisa Nurma menyiapkan diri menjadi perempuan pengusaha atas planning bersama dengan suaminya kini, mereka merintis usaha bersama kemudian mengembangkan usaha tersebut hingga sekarang memiliki 3 jenis usaha dengan omzet lebih dari Rp 500.000.000 perbulannya. Hampir sama dengan yang dilakukan oleh Rahma Fauzia, Alya Mirza, Anisa Yona, Novi Ana dan Iffah M Dewi, mereka sudah memulai usaha sejak ada di bangku kuliah, sebelum bertemu dengan pasangan mereka sudah menekuni profesi ini. Hal tersebut tidak membuat mereka kesulitan menyesuaikan kesibukan masing-masing, justru mereka mampu beradaptasi dengan profesi dan bahkan ketika sudah menjadi suami mereka saling menguatkan untuk terus mengembangkan bisnis tersebut.

Dia keluar dari kerjaannya, bantu aku. Karena ngerti kesibukanku yaudah dia akhirnya resign dan dirumah sekarang." (wawancara dengan Iffah $M$ Dewi, 17 Januari 2019)

Contoh lain, suami Anisa Yona, Iris Haribaning dan Vira Denis justru memilih resign dari pekerjaannya kemudian mendedikasikan tenaganya untuk membantu kegiatan wirausaha para informan. Tentu hal ini menjadi 
tantangan tersendiri bagi ketiga informan tersebut, mereka memposisikan sebagai seorang istri dan juga sebagai rekan kerja sebab, kendala-kendala mengenai pekerjaan acapkali menjadikan situasi menjadi canggung. Namun, mereka menepis hal tersebut, bahkan untuk beberapa hal yang nyata mereka bekerja bersama suami justru saling melengkapi. Hal yang paling menonjol misalnya karena gerak mereka terbatas dalam hal waktu dan tenaga, para suami ini menjadi pengganti peran dalam urusan rumah tangga.

Para suami dari perempuan pengusaha secara fleksibel menempatkan perannya dalam urusan domestik seperti merawat anak. Hal ini menjadi pertimbangan dan membutuhkan komunikasi pasangan dalam urusan mengatur rumah tangga. Walaupun bagi para suami perempuan pengusaha tentu memilih antara pekerjaan dengan membantu kesibukan istri dan mengerti kegiatannya hal kompleks untuk dipertimbangkan bahkan untuk dipilih sekalipun (cf. Choo \& Ferree, 2010: 134). Tetapi dengan kemauan dan keinginan mereka untuk membangun usaha bersama dan atas kerelaannya melepaskan profesinya pola seimbang tersebut dapat tercapai. Bahkan dengan itu, mereka pun harus berkorban tenaga dan waktu juga materi untuk membantu mengembangkan bisnis tersebut. Para suami perempuan pengusaha yang concern untuk membantu istrinya berwirausaha juga secara fleksibel menempatkan diri sebagai mitra kerja.

Suamiku support dengan apa yang aku lakukan, dia support tenaga waktu untuk bantu, materi juga (wawancara dengan Rahma Fauzia, 29 Januari 2019)

Perempuan pengusaha mampu menjalankan multiperan mereka dalam dua ranah berbeda yaitu domestik dan publik melalui negosiasi dan menempatkan agensi. 
Adanya dukungan dari keluarga terutama suami mereka membuat usaha yang mereka geluti kian berkembang. Dengan demikian, dapat menggabungkan modal dan berkolaborasi menghasilkan suatu produk, misalnya dengan membuka cabang-cabang baru atau mendukung dari segi ide dan inovasi produk. Hal ini diuraikan oleh seluruh Informan Iffah M dewi, Tria Meriza, Reisa Nurma, Rahma Fauzia, Alya Mirza, Novi Anna, dan lainnya bahwa dukungan dari suami juga menentukan bagimana cara dan pengembangan usaha mereka. Iffah M Dewi membuat bekerjasama dengan suaminya membangun Perseroan Terbatas (PT) yang memproduksi berbagai barang, di luar usaha batik mereka, Sogan Batik, yang telah mapan. Kini mereka menjadikan sogan batik sebagai salah satu brand merek dari PT Jaya Abadi.

Dari bidang kuliner, Rahma Fauzia dengan produk kuliner@segosambeliwakpe dalam waktu beberapa bulan sudah memiliki 3 cabang warung lesehan. Hal ini dia lakukan berkolaborasi dengan suaminya yang mendukung penuh kegiatan usaha yang dia lakukan. Para pengusaha perempuan ini merasa bahwa dalam beberapa hal yang terkait dengan passion dan negosiasi dengan suami dapat menghasilkan kemajuan perkembangan usaha. Pentingnya dukungan suami dalam membangun dan menjalankan usaha ini memerlukan komunikasi dan diskusi yang intens dan bernegosiasi atas peran-peran yang meraka lakukan sebagai pengusaha dan perempuan yang sudah berkeluarga.

Cerita di atas menggambarkan bahwa negosiasasi antara suami dan istri berorientasi pada penentuan prioritas, agenda, ketepatan, dan memaksimalkan produktivitas mereka sesuai pada tempatnya (Goode, 1983: 201). Selain itu, suami juga perlu berkesadaran sebagai partner kerja dan pasangan hidup yang mendukung aktivitas berwirausaha mereka. Oleh karena itu, negosiasi peran ini bersifat fluid, sesuai dengan 
kondisi dan dengan siapa para perempuan pengusaha ini berinteraksi baik dengan keluarga dan pekerjaan (cf. Braches \& Elliott, 2016: 541; Pines, 2002: 173; Pistrui dkk., 2000: 255). Para perempuan pengusaha menempatkan diri mereka sebagai agen yang aktif dalam relasi kompleks multi-peran seperti ini (Chapman \& Benis, 2017: 83; Warner \& Brown, 2011: 1239).

\section{SIMPULAN}

Para perempuan pengusaha memanfaatkan teknologi digital khususnya Instagram sebagai alat untuk mengidentifikasi dan memanfaatkan perkembangan tren konsumen. Dalam proses ini mereka membranding dirinya sebagai pengusaha yang inspiratif dan membranding produk/ jasa mereka dengan tujuan menangkap serta memanfaatkan peluang usaha yang lebih besar. Mereka menggunakan kejeliannya untuk melakukan analisis yang detail terkait segmentasi pasar yang mereka targetkan melalui pemasaran digital yang menitikberatkan pada visualisasi konten Instagram.

Aspek yang terus mereka kembangkan adalah inovasi dan kreativitas serta adaptasi mereka terhadap perubahan setting media sosial yang berubah dengan pesat. Pemanfaatan teknologi yang dilakukan oleh para perempuan pengusaha ini menunjukkan bahwa mereka mampu memanfaatkan media digital menjadi peluang ekonomi yang menguntungkan. Peluang berwirausaha yang mereka tangkap dalam era ekonomi digital ini terus mereka olah dan kembangkan dengan cara mengekplorasi wawasan melalui kegiatan coaching dan komunitas produktif yang mereka ikuti.

Pada saat yang sama, para perempuan pengusaha ini menegosiasikan peran antara fungsi domestik rumah tangga dengan aktivitas kewirausahaan dengan cara menempatkan peran mereka sebagai perempuan secara fluid. Di tengah kesibukan mereka sebagai pengusaha yang harus menangani masalah karyawan dan pengembangan usaha, para perempuan 
ini memiliki tanggung jawab domestik yang harus dilakukan. Oleh karena itu, para perempuan ini menyinergikan peran mereka melalui breakdown agenda secara sistematis. Melalui agenda tersebut mereka dapat memilah tentang bagian mana dari pekerjaan yang bisa didelegasikan dan mereka tidak harus bekerja secara langsung. Hal yang penting dalam negosiasi peran ini adalah negosiasi yang diplomatis dengan keluarga terutama suami mengenai peran perempuan, sebab kehidupan domestik rumah tangga melibatkan interaksi yang intens dengan suami sebagai mitra kehidupan rumah tangga sekaligus kerja.

Para perempuan ini menekuni pekerjaan sebagai wirausaha dengan aktifitas yang padat karena mereka harus dapat berpikir secara tepat dan akurat. Pola pikir tersebut mereka dapatkan melalui proses pengalaman dan berkembangnya wawasan mengelola usaha sehingga di samping memiliki kesibukan dalam menjalankan aktivitas wirausaha, mereka juga mampu mengartikulasikan diri mereka dalam dua peran yang mereka mainkan secara fleksibel. Selain itu, mereka juga merepresentasikan bahwa perempuan memiliki daya untuk dapat mengembangkan diri melalui aktualisasi sebagai wirausaha tanpa meninggalkan peran mereka sebagai seorang perempuan yang telah berkeluarga. 


\section{DAFTAR PUSTAKA}

Allen, M. 2018. Social Media Marketing of Qualitative Research: Blurring Commerce and Community. Qualitative Inquiry. Vol. 1(8): 591-598.

Angel, P., Jenkins, A., \& Stephens, A. 2018. Understanding Entrepreneurial Success: A Phenomenographic Approach. International Small Business Journal: Researching Entrepreneurship. Vol. 6(36): 611-636.

Antonio, A., \& Tuffley, D. 2014. The Gender Digital Divide in Developing Countries. Future Internet. Vol. 6(4): 673-687. https:// doi.org/10.3390/fi6040673

Armstrong, C. G., Delia, E. B., \& Giardina, M. D. (2016). Embracing the Social in Social Media: An Analysis of the Social Media Marketing Strategies of the Los Angeles Kings. Communication \& Sport. Vol. 4(2): 145-165. https:/ / doi.org/10.1177/2167479514532914

Bal, A. S., Grewal, D., Mills, A., \& Ottley, G. 2015. Engaging Students With Social Media. Journal of Marketing Education. Vol. 3(37): 190-203.

Beckert, J., Dave Elder-Vass. 2017. Digital Economy.Profit and Gift in the Digital Economy. European Journal of Sociology. Vol. 03(58): 506-511.

BEKRAF. 2017. Data Statistik dan Hasil Survei: Ekonomi Kreatif. Diakses di http://www.bekraf.go.id/downloadable/ pdf_file/170475-data-statistik-dan-hasil-survei-ekonomikreatif.pdf diakses pada pada 23 Oktober 2018.

BPS. 2018. Ekonomi Indonesia Triwulan II-2018 Tumbuh 5,27 Persen.

Diakses di https://www.bps.go.id>2018/08/06 diakses pada tanggal 10 Oktober 2018.

Burke dkk. 2002. Self-Employment, Wealth and Job Creation: The Roles of Gender, Non-Pecuniary Motivation and Entrepreneurial Ability. Small Business Economics. Vol. 3(19): 255-270.

Braches, B., \& Elliott, C. 2016. Articulating the Entrepreneurship Career: A Study Of German Women Entrepreneurs. International Small Business Journal. pp 535-557 
Bretones, F. D., Cappello, H. M., \& Garcia, P. A. 2009. Social and Cultural Influences among Mexican Border Entrepreneurs. Psychological Reports. Vol. 104(3), 844-852.

CfDS. 2017. Young Microcelebrities in Indonesia: The Case of Instagram. Diakses di cfds.fisipol.ugm.ac.id

Elder-Vass, D. 2016. Profit and Gift in the Digital Economy (First published). Cambridge, United Kingdom: Cambridge University Press.

Essers, C., \& Benschop, Y. 2009. Muslim Businesswomen Doing Boundary Work: The Negotiation of Islam, Gender and Ethnicity Within Entrepreneurial Contexts. Human Relations. Vol. 62(3), 403-423.

Fakih, M. 2008. Analisis Gender dan Transformasi Sosial. Yogyakarta: Insist Press.

Fisher, E. 2015. 'You Media': Audiencing as Marketing In Social Media. Media, Culture E Society. Vol. 37(1): 50-67. https:/ / doi.org/10.1177/0163443714549088

Flanagan, F. 2018. Theorising the gig economy and home-based service work. Journal of Industrial Relations. pp. 01-22 002218561880051. https://doi. org/10.1177/0022185618800518

Gandini, A. 2016. Digital Work: Self-Branding and Social Capital in The Freelance Knowledge Economy. Marketing Theory. Vol. 16(1): 123-141. https://doi. org/10.1177/1470593115607942

García, M.-C. D., \& Welter, F. 2013. Gender Identities and Practices: Interpreting Women Entrepreneurs' Narratives. International Small Business Journal. Vol. 31(4): 384-404.

Hamilton E. 2006. Whose Story Is It Anyway? Narrative Accounts of The Role of Women in Founding and Establishing Family Businesses dalam Stead, Valerie. (2017). Belonging and Women Entrepreneurs: Women's Navigation of Gendered Assumptions in Entrepreneurial Practice. International Small Business Journal 2017. Vol. 35(1): 61 -77. 
Hopkinson, G., \& Aman, A. 2017. Women Entrepreneurs: How Power Operates In Bottom Of The Pyramid-Marketing Discourse. Marketing Theory. Vol. 17(3): 305-321. https:// doi.org/10.1177/1470593117704280

In Lohsse, S., In Schulze, R., \& In Staudenmayer, D. 2018. Trading Data In The Digital Economy: Legal Concepts And Tools: Münster Colloquia on EU law and the digital economy III. London : Bloomsbury Publishing

Jayawarna, D., Rouse, J., \& Kit ching, J. 2013. Entrepreneur Motivations and Life Course. International Small Business Journal. Vol. 31(1): 34-56. https://doi. org/10.1177/0266242611401444

Kabeer, N. 2001. Resources, agency, achievement: reflections on the measurement of women's empowerment. Power, Resources and Culture in a Gender Perspective : Towards a Dialogue between Gender Research and Development Practice : Proceedings from a Conference Arranged by the Collegium for Development Studies, Uppsala University, in Cooperation with Sida 26-27 October, 2000. pp. 69-73. https:/ / daringlibrary.wiley.com/ doi/pdf/10.1111/14677660.00125

Lohsee, Sebastian/ Staudenmayer, Dirk/ Schulze, Reiner (ed.), Trading data in Digital Economy: Legal Concepts and Tools. Munster Colloquia on EU Law and the Digital Economy III, Baden-Baden, pp. 75-100

Martínez-Cantos, J. L. (2017). Digital Skills Gaps: A Pending Subject for Gender Digital Inclusion In The European Union. European Journal of Communication. Vol. 32(5): 419438. https:// doi.org/10.1177/0267323117718464

Meliou, E., \& Edwards, T. (2018). Relational Practices and Reflexivity: Exploring The Responses Of Women Entrepreneurs To Changing Household Dynamics. International Small Business Journal: Researching Entrepreneurship. Vol. 36(2): 149-168. https://doi. org/10.1177/0266242617724858

O'Mara, B., Gill, G. K., Babacan, H., \& Donahoo, D. 2012. Digital Technology, Diabetes and Culturally and 
Linguistically Diverse Communities: A Case Study With Elderly Women From The Vietnamese Community. Health Education Journal. Vol. 71(4): 491-504. https:// doi. org/10.1177/0017896911407054

Pareek, P., \& Bagrecha, C. 2017. A Thematic Analysis of the Challenges and Work-Life Balance of Women Entrepreneurs Working in Small-Scale Industries. Vision: The Journal of Business Perspective. Vol. 21(4): 461-472. https:/ / doi.org/10.1177/0972262917739181

Pistrui, D., Welsch, H. P., Wintermantel, O., Liao, J., \& Pohl, H. J. 2000. Entrepreneurial Orientation and Family Forces in the New Germany: Similarities and Differences between East and West German Entrepreneurs. Family Business Review. Vol. 13(3): 251-264. https://doi.org/10.1111/ j.1741-6248.2000.00251.x

Ratten, V., \& Dana, L.-P. 2017. Gendered Perspective of Indigenous Entrepreneurship. Small Enterprise Research. Vol. 24(1): 62-72. https://doi.org/10.1080/13215906.2017 .1289858

Rioux, J., \& Parylak, J.-A. 2016. Dear Daycare Parent: The MustHave Guide To Daycare for Working Parents: Over 101 Ways to Improve Your Child's Experience. Newington, Connecticut: Rioux Advisory Group, LLC,.

Sakai, Minako. 2018. Penggiat Bisnis Syariah: Muslimah, Kewirausahaan, Dan Pemberdayaan Masyarakat. Jakarta: Dompet Dhuafa.

Sakai, M., \& Fauzia, A. 2016. Performing Muslim Womanhood: Muslim Business Women Moderating Islamic Practices in Contemporary Indonesia. Islam and Christian-Muslim Relations. Vol. 27(3): 229-249. https://doi.org/10.1080/09 596410.2015.1114243

Salem, S. F., \& Salem, S. O. 2019. Effects of Social Media Marketing and Selected Marketing Constructs on Stages of Brand Loyalty. Global Business Review. https://doi. org/10.1177/0972150919830863 
Sharma, K., \& Kumar, P. 2018. Book review: Tracy L. Tuten and Michael R. Solomon, Social Media Marketing. Vision: The Journal of Business Perspective. Vol. 22(2): 241-242. https:/ / doi.org/10.1177/0972262918766148

Stead, V. 2017. Belonging and Women Entrepreneurs: Women's Navigation of Gendered Assumptions In Entrepreneurial Practice. International Small Business Journal. Vol.. 35(1): 61-77. https://Doi.Org/10.1177/0266242615594413

Thackeray, R., Neiger, B. L., \& Keller, H. 2012. Integrating Social Media and Social Marketing: A Four-Step Process. Health Promotion Practice. Vol. 13(2): 165-168. https://doi. org/10.1177/1524839911432009

Tham, J. 2013. Book Review: The Zen of Social Media Marketing: An Easier Way to Build Credibility, Generate Buzz, and Increase Revenue, by Shama Hyder Kabani. Journalism $\mathcal{E}$ Mass Communication Quarterly, Vol. 90(3): 590-591.

Turner, dkk. 2000. Looking to Initiatives in Communications Technology to Overcome Social Exclusion and Gender Inequalities: Women's Mobility and Welfare to Work: The Need for Appropriate Transport Policies, 15(1), ISSN 0269-0942

Wang, W. 2018. The Differentially Associated Sharing Economy. New Media E Society. Vol. 20(11): 4237-4254. https:// doi. org/10.1177/1461444818769572

Goode, William. J. 1983. Sosiologi Keluarga. Jakarta: Bina Aksara.

Zimmermann, Hans-Dieter. 2018. Understanding the Digital Economy: Challenges for new Business Models. pp. 729-732. 